\title{
Megnyilvánuló komparatív előnyök a magyar mezőgazdaságban: kaotikus vagy koherens szerkezet?
}

\begin{abstract}
A cikk a magyar mezőgazdaság megnyilvánuló komparatív elönyeit vizsgálja a Balassa- index alkalmazásával 1992 és 2002 között különböző referenciapiacokon és aggregációs szinten. Eredményeink azt mutatják, hogy a magyar mezőgazdaság megnyilvánuló komparatív előnyei meglehetősen változékonyak mind az egyes aggregációs szintek között, mind a különböző referenciapiacok között. A kereskedelem specializációja csökkenő trendet mutat mindegyik referenciacsoportban, azaz a hazai agrárszektor elveszítette komparatív elönyeit számos termékcsoportban a vizsgált időszakban. A B-indexek közelebbi elemzése azt mutatja, hogy azok konvergáltak egymáshoz, de az egyes termékcsoportoknál az indexek nagyobb változékonyságot mutattak. Meglehetösen nagy annak a valószínüsége, hogy egy termékcsoport specializációja csökkenjen, míg annak növekedésére alig van esély.

Kulcsszavak: komparatív elönyök, magyar mezőgazdaság

Journal of Economic Literature (JEL) kód: Q 12
\end{abstract}

\section{Bevezetés}

A megnyilvánuló komparatív előnyök koncepciója komoly karriert futott be a nemzetközi kereskedelem empirikus elemzésében. Noha Balassa (1965) eredeti javaslatát a megnyilvánuló komparatív előnyök mérésére az elmúlt évtizedekben sokan próbálták javítani, illetve módosítani, mégis az eredeti Balassa-index maradt továbbra is a leggyakrabban használt elemzési eszköz az empirikus kutatásokban (Fertő (2003b). A Balassa-indexet és más hasonló mérőszámokat több referenciacsoporthoz (pl. világpiac, OECD, EU stb.) is ki lehet számolni. Richardson - Zhang (1999) munkája kivételével azonban eddig nem született vizsgálat arról, hogy a megnyilvánuló komparatív elönyök szerkezete hogyan változik szimultán módon a különböző regionális piacokon, az idő változásával és az egyes szektorok között. Korábbi vizsgálataink arra utaltak, hogy a magyar agrárszektor komparatív előnyei különbözők lehetnek a világpiacon és az Európai Unióban, illetve azok szerkezete időben is változhat (Fertő 2004). Az eddigi szórványos empirikus tanulmányok eredményei alapján ezért indokolt feltenni a kérdést: mennyire stabilak a komparatív elönyök az egyes referencia piacok között (pl.

\footnotetext{
" A szerző az MTA Közgazdaságtudományi Intézetének és a Budapesti Corvinus Egyetem Agrárgazdaságtan és Vidékfejlesztési Tanszékének tudományos fömunkatársa. A cikk alapjául szolgáló kutatást az OTKA T037868 sz. Kereskedelemelmélet és magyar agrárkereskedelem címü programja támogatta.
} 
EU, OECD, világpiac stb.), illetve vajon változnak-e az idő múlásával? Míg az utóbbi kérdésre az elmúlt években egyre több tanulmány keresi a választ (pl. Brasili és társai 2000; Proudmann - Redding 2000; Hinloopen - van Marrevijk 2001; Fertö 2003a; Fertö - Hubbard 2003; 2005), addig az első probléma mindeddig kívül maradt a kutatások érdeklődési körén.

A nemzetközi kereskedelem empirikus elemzésénél az egyik kiinduló kérdés, hogy milyen mély bontású adatokat használjunk. Nincs ez másképp a megnyilvánuló komparatív előnyök vizsgálatánál sem. A különböző kutatások összehasonlítását ugyanis nagyban megnehezíti, hogy a szerzők általában különböző aggregációs szinten végezték el vizsgálatukat. Richardson - Zhang (1999) munkájától eltekintve azonban nem vizsgálták meg eddig, hogy az miképp befolyásolja az eredményeket, ha a Balassa-indexeket eltérő aggregáltsági szinten számoljuk ki. Nyilvánvaló, hogy a Balassa-index értéke termékcsoportról termékcsoportra változik, de ezek a különbségek érdekes módon eltérhetnek aszerint, hogy miképp definiáljuk a termékcsoportokat. Hazánknak lehetnek megnyilvánuló komparatív előnyei mélyebb bontású termékcsoportokban, míg ezek eltünhetnek magasabb aggregációs szinten. Ugyanakkor ennek az ellenkezője is igaz lehet.

A dolgozat több ponton járul hozzá a jelenlegi irodalomhoz. Egyrészt, korábbi tanulmányainkat kiegészítve (Fertő 2003a, Fertő - Hubbard 2003 és 2005), a magyar agrárkereskedelem komparatív előnyeit egyszerre nem csak egy, hanem párhuzamosan több referenciapiacon is megvizsgáljuk. Másrészt, részletesen elemezzük a külkereskedelmi adatok különböző aggregációs szintjének hatását az eredményekre. Végezetül, a nemzetközi kereskedelem empirikus irodalmában alkalmazott legújabb módszertani eszközöket hasznosítjuk a magyar agrárkereskedelem szerkezetének elemzésében.

A tanulmány célja ezért, hogy több szempontból is részletesen elemezze a megnyilvánuló komparatív előnyök szerkezetének változásait a magyar mezőgazdaság példáján keresztül. A dolgozat szerkezete a következő. Először röviden áttekintjük az alkalmazott módszertant. Ezt követően három részben ismertetjük eredményeinket. Először az aggregáció problémájával foglalkozunk. Másodszor a Balassa-indexek eloszlását veszszük szemügyre. Harmadszor a magyar agrárexport strukturális változásait elemezzük. Végezetül összefoglaljuk eredményeinket és megfogalmazunk néhány következtetést.

\section{Az alkalmazott módszertan}

A tanulmányban a Brasili és társai (2000), Proudman és Redding (2000) valamint Hinloopen és van Marrewijk (2001) által alkalmazott módszertant követjük. Míg ezek a tanulmányok kizárólag az ipari ágazatokkal foglalkoztak, mi az élelmiszer-gazdaságra koncentrálunk, és megvizsgáljuk a B-indexek stabilitását Magyarország esetében. A megnyilvánuló komparatív előnyök eredeti verzióját Balassa (1965) fejlesztette ki, és a következőképpen definiálta:

$$
\mathrm{B}=\left(\mathrm{x}_{\mathrm{ij}} / \mathrm{x}_{\mathrm{it}}\right) /\left(\mathrm{x}_{\mathrm{nj}} / \mathrm{x}_{\mathrm{nt}}\right)
$$

ahol x reprezentálja az exportot, i egy adott országot, $\mathrm{j}$ egy meghatározott terméket, $\mathrm{t}$ a termékek egy csoportját, valamint $\mathrm{n}$ az országok egy adott csoportját. B a megfigyelt kereskedelem szerkezetén alapul, egy meghatározott termék arányát a teljes hazai ex- 
portban veti össze ennek a terméknek egy meghatározott országcsoport kereskedelmében betöltött részesedésével. $\mathrm{Ha} \mathrm{B}>1$, akkor megnyilvánuló komparatív előnyről beszélhetünk. Könnyen belátható, hogy a B-index kiterjeszthető egy olyan globális mércévé, amely minden terméket (t) és minden országot (n) magában foglal (Vollrath 1991).

Hillman (1980) elméleti megalapozást adott a Balassa-indexnek, és kidolgozott egy empirikusan is ellenőrizhető feltételt, amelynek teljesülése esetén a Balassa-index alkalmazható a komparatív elönyök mérésére ${ }^{1}$.

A tanulmányban a B-indexek stabilitására koncentrálunk az idő folyamán az egyes referenciacsoportokban, és azok között. Kétféle stabilitást különböztethetünk meg. Egyrészt, a B-indexek eloszlásának stabilitását egyik periódusról a másikra. Másrészt, a Bindexek értékének a stabilitását az adott termékcsoportokban egyik periódusról a következöre (Hinloopen and Van Marrewijk 2001).

$\mathrm{Az}$ első típusú stabilitást többféleképpen vizsgáljuk. Egyrészt, Brasili és társai (2000) valamint Hinloopen és Van Marrewijk (2001) módszerét alkalmazva a B-index eloszlásának formáját Kernel-féle sűrűségfüggvény alkalmazásával elemezzük.

Másodszor, Dalum és társai (1998), Laursen (2000) javaslatát követve regressziós elemzést alkalmazunk annak vizsgálatára, hogy a B-index értéke mennyire és hogyan változott. Korábbi kutatásainkban (pl. Fertö 2003a; Fertő és Hubbard 2005) a B-index szimmetrikus transzformációját (RSCA) alkalmaztuk a regressziós elemzésben, hogy elkerüljük a B-index ferdeségéből származó problémákat. Eredményeink azonban nem lettek szignifikánsan jobbak a módosított index alkalmazásával sem, ezért úgy döntöttünk, hogy a jelen vizsgálatban maradunk az eredeti mérőszámnál. Ennek megfelelően a következő regressziót becsüljük:

$$
B_{i j}^{t 2}=\alpha_{i}+\beta_{i} B_{i j}^{t 1}+\varepsilon_{i j},
$$

ahol t1 és t2 felső indexek a kezdő és a végső évet jelölik. A függő változó, B t2 időpontban i szektorban j országban, tesztelték a független változóval, amelyből B t1 megelőző év; $\alpha$ és $\beta$ a standard lineáris regresszió paraméterei és $\varepsilon$ a reziduális tag. A regresszió mögött húzódó megfontolás az, hogy ha $\beta=1$, akkor az B-index eloszlásának változatlanságát mutatja t1 és $\mathrm{t} 2$ periódus között. Ha $\beta>1$, akkor az adott ország még jobban azokra a termékekre specializálódik, amelyekre már korábban is specializálódott, illetve egyre kevésbé specializálódik azokra a termékekre, amelyekre korábban sem specializálódott. Más szavakkal, az adott ország már meglévő specializációja tovább erősödött. Ha $0<\beta<1$, ez azt jelenti, hogy azon termékcsoportok értéke, amelyek kezdetben alacsony vagy negatív B-indexekkel voltak jellemezhetők, növekedett az idővel, míg a magas és pozitív B-indexekkel rendelkező termékcsoport értéke csökkent. Speciális esetben, ha $\beta<0$, ez arra utal, hogy az index előjele megváltozott. Dalum és társai (1998) rámutatnak arra, hogy $\beta>1$ nem szükséges feltétele az általános specializáció növekedésének. Ezért a szerzők, Cantwell (1989) munkáját követve, úgy érvelnek, hogy megmutatható:

$$
\sigma_{i}^{2 t 2} / \sigma_{i}^{2 t 1}=\beta_{i}^{2} / R_{i}^{2}
$$

${ }^{1}$ A Hillman-feltételről magyarul bővebben lásd: (Fertő 2003b). 
Ezért,

$$
\sigma_{i}^{t 2} / \sigma_{i}^{t 1}=\left|\beta_{i}\right| /\left|R_{i}\right|,
$$

ahol R korrelációs koefficiens a regressziós egyenletből és $\sigma^{2}$ a függő változó varianciája. Ebböl az következik, hogy egy adott eloszlás szerkezete változatlan, ha $\beta=R$. Ha $\beta>R$, akkor a specializáció foka növekszik, míg ha $\beta<R$, akkor a specializáció foka csökken.

Harmadszor, nemcsak arra vagyunk kíváncsiak, hogy miként alakul a B-indexek eloszlása az egyes piacokon, hanem azt is megvizsgáljuk, miként alakult azok eloszlása az egyes referenciacsoportokhoz viszonyítva. Amiti (1998 és 1999) nyomán Gini-koefficiensekkel mérjük, hogy mekkora a különbség a magyar agrárexport és a referenciacsoportok agrárexportjának specializációja között. A Gini-index értéke 0 és egy között mozog. Ha a Gini-együttható közel van egyhez, akkor ez azt jelenti, hogy hazánk agrárexportja specializációjának a szerkezete megegyezik a referenciacsoportok mezőgazdasági exportja specializácójával. Ha az index közel van egyhez, akkor az arra utal, hogy Magyarország teljesen egy olyan termék exportjára specializálódik, amelynek kicsi a részesedése a referenciacsoport exportjában.

A második típusú stabilitás elemzésére Proudman és Redding (2000) Brasili és társai (2000) és Hinloopen és Van Marrewijk (2001) munkáit követve átmeneti valószínűségi mátrixokat alkalmazunk a B-index tartósságának és mobilitásának meghatározására. A B-indexeket különböző osztályközökbe sorolhatjuk, és ez alapján számolhatjuk ki az átmeneti valószínűségi mátrixokat. Az irodalomban alapvetően két megoldás terjedt el. A tanulmányok többsége a B-indexeket valamilyen percentilisbe sorolja (általában kvartilisbe), mint például Proudman és Redding (2000), Brasili és társai (2000), Redding (2002). A másik módszer, Hinloopen és Van Marrewijk (2001) munkáját követve négy csoportba oszthatjuk a B-indexeket:

Osztály $a: 0<\mathrm{B} \leq 1$;

Osztály $b: 1<\mathrm{B} \leq 2$

Osztály $c: 2<\mathrm{B} \leq 4$;

Osztály $d: 4<\mathrm{B}$.

Az a osztály azokat a termékeket mutatja, ahol nincs komparatív előny. A másik három osztály, $b, c$, és $d$ a komparatív előnyökkel rendelkező termékeket mutatja, durván az alábbi csoportosításban: gyenge komparatív előny ( $b$ osztály), közepes komparatív előny ( $c$ osztály) és erős komparatív előny (d osztály). Ennek az eljárásnak az előnye, hogy könnyen értelmezhetö. A különböző percentilisen alapuló vizsgálatok esetében ugyanis gyakran előfordul, hogy több percentilis is egynél kisebb, ezért közgazdaságilag nehéz értelmezni kapott eredményeket, ha az adott jószág B-indexének az értéke két egynél kisebb percentilis között mozog két időpont között. A másik előnye abból származik, ha a kutatás során több ország kereskedelmi szerkezetében végbement változásokat akarjuk összehasonlítani. Ebben az esetben ugyanis az egyes országok percentiliseinek az értéke nagy valószínüséggel különbözik egymástól, ami megakadályozza a korrekt elemzést. Ha viszont követjük a Hinloopen és Van Marrewijk (2001) által javasolt csoportosítást, akkor az országok közötti összehasonlításnak könnyen azonosítható közgazdasági értelmezése van. 
Másodszor, a specializáció szerkezete mobilitásának fokát a mobilitási indexek segítségével vizsgálhatjuk. Ezek formálisan értékelik a mobilitás fokát a B-index teljes eloszlásán keresztül, és lehetővé teszik az országok és/vagy referenciapiacok közötti öszszehasonlítást. Az első index $M_{1}$ (Shorrocks 1978) az átmeneti valószínüségi mátrixok nyomát (tr) vizsgálja.

$$
\mathrm{M}_{1}=\frac{\mathrm{K}-\mathrm{r}(\mathrm{P})}{\mathrm{K}-1},
$$

ahol $\mathrm{K}$ a cellák száma, és $\mathrm{P}$ az átmeneti valószínüségi mátrix.

A második index $\mathrm{M}_{2}$, (Shorrocks 1978; Geweke és társai 1986) átmeneti valószínüségi mátrixok determinánsára (det) koncentrál.

$$
\mathrm{M}_{2}=1-|\operatorname{det}(\mathrm{P})| \text {. }
$$

Mindkét indexnél a magasabb értékek a nagyobb mobilitásra utalnak, míg a nulla érték a tökéletes immobilitást mutatja.

\section{Empirikus eredmények}

Jelen tanulmányban Magyarország agrárkereskedelme szerkezetének dinamikájával foglalkozunk 1992-2002 között. A B-indexeket öt különböző referenciacsoportra számoltuk ki, melyek a következők: világpiac, fejlett országok, Európai Unió, fejlődő országok, közép-európai országok ${ }^{2}$. Az EU esetében a 15 tagállamot vettük figyelembe, míg a közép-európai országoknál az EU-hoz újonnan csatlakozó nyolc ország közül csak hetet vettünk figyelembe (Csehország, Észtország, Lengyelország, Lettország, Litvánia, Szlovákia és Szlovénia), mert hazánkat a halmozódás problémája miatt kihagytuk. A vizsgálat során használt adatok az UNCTAD adatbázisból származnak SITC rendszerben (Standard International Trade Classification). Az SITC rendszer háromszámjegyü bontásában 59 termékcsoportból áll a teljes minta. Marchese és Nadal de Simone (1989), valamint Hinloopen és van Marrewijk (2004) javaslatát követve, teszteltük a Hillmanfeltételt az adatbázisunkra. Eredményeink azt mutatták, hogy a B-indexek kiszámítása teljesen konzisztens a Hillman-feltétellel.

\section{Az aggregáció problémája}

A Balassa-indexeket három különböző aggregáltsági szinten számoltuk ki: az SITC egy-, kettő- és háromszámjegyü bontásában 1992 és 2002 között mindegyik referenciacsoportban. Az áttekinthetőség kedveért csak a B-indexek átlagát mutatjuk be, de a részletesebb évenkénti eredmények is közel azonos eredményt mutatnak. Számításaink ismertetését a legmagasabb aggregáltsági szinten kezdjük.

${ }^{2}$ A fejlett és a fejlődő országok csoportjába sorolt országok listáját lásd: www.unctad.org. 
1. táblázat

A B-indexek átlaga termékcsoportonként és régióként 1992 és 2002 között

\begin{tabular}{lccccc}
\hline & $\begin{array}{c}\text { Világ- } \\
\text { piac }\end{array}$ & $\begin{array}{c}\text { Fejlett } \\
\text { országok }\end{array}$ & $\begin{array}{c}\text { Európai } \\
\text { Unió }\end{array}$ & $\begin{array}{c}\text { Fejlődő } \\
\text { országok }\end{array}$ & $\begin{array}{c}\text { Közép-európai } \\
\text { országok }\end{array}$ \\
\hline 0 Élelmiszer, élö állatok & 1,75 & 1,84 & 1,61 & 1,52 & 2,48 \\
1 Italok, dohány & 1,09 & 0,97 & 0,75 & 1,53 & 1,33 \\
2 Nyersanyagok & 1,17 & 1,28 & 1,87 & 1,07 & 0,73 \\
$\begin{array}{l}\text { 4 Állati és növényi olajok és } \\
\text { zsírok }\end{array}$ & 1,16 & 1,74 & 1,43 & 0,63 & 2,62 \\
\hline
\end{tabular}

Forrás: A szerző számításai az UNCTAD adatbázis alapján SITC rendszerben egyszámjegyü bontásban.

Megjegyzés: a besötétített számok azt mutatják, hogy melyik termékcsoportban nincs megnyilvánuló komparativ elöny.

Az 1. táblázat tanúsága szerint a magyar agrárexportnak mindegyik terméknél vannak megnyilvánuló komparatív előnye, termékcsoportonként legalább három referenciacsoportban. Az élelmiszerek és élőállatok esetében Magyarországnak mindegyik referenciapiacon van megnyilvánuló komparatív előnye. Hazánknak nincs komparatív előnye az Európai Unióban és a fejlett országokban az italoknál és a dohánynál. A nyersanyagok és az állati és növényi olajok esetében Magyarországnak nincs megnyilvánuló komparatív előnye a közép-európai országokban, illetve a fejlődő országokban.

2. táblázat

\section{A B-indexek átlaga termékcsoportonként és régióként 1992 és 2002 között kétszámjegyü bontásban}

\begin{tabular}{lccccc}
\hline Termékcsoport & $\begin{array}{c}\text { Világ- } \\
\text { piac }\end{array}$ & $\begin{array}{c}\text { Fejlett } \\
\text { országok }\end{array}$ & $\begin{array}{c}\text { Európai } \\
\text { Unió }\end{array}$ & $\begin{array}{c}\text { Fejlődő } \\
\text { országok }\end{array}$ & $\begin{array}{c}\text { Közép-európai } \\
\text { országok }\end{array}$ \\
\hline 00 Élöállat & 3,57 & 3,23 & 2,86 & 5,40 & 3,22 \\
01 Hús és húskészítmény & 4,43 & 3,78 & 3,37 & 8,20 & 6,99 \\
02 Tejtermék, tojás & 0,72 & 0,55 & 0,39 & 4,55 & 0,70 \\
03 Hal, rák, puhatestú állat & 0,04 & 0,06 & 0,08 & 0,02 & 0,08 \\
04 Gabona, gabonakészítmény & 1,83 & 1,65 & 1,91 & 2,45 & 3,27 \\
05 Zöldségféle és gyümölcs & 2,07 & 2,44 & 1,67 & 1,45 & 3,08 \\
06 Cukor, cukorkészítmény, méz & 0,94 & 1,34 & 1,01 & 0,53 & 0,90 \\
07 Kávé, tea, kakaó, füszer & 0,72 & 1,24 & 0,86 & 0,34 & 1,74 \\
08 Állati takarmány & 0,99 & 1,07 & 1,13 & 0,88 & 2,55 \\
09 Egyéb, táplálkozásra alkalmas & 2,07 & 1,78 & 1,51 & 3,53 & 2,91 \\
termék és készítmény & & & & & \\
\hline 11 Ital & 1,62 & 1,32 & 0,86 & 4,01 & 1,91 \\
12 Dohány és dohányáru & 0,35 & 0,37 & 0,41 & 0,31 & 0,45 \\
\hline 21 Nyersbőr és kikészítetlen szőrme & 0,54 & 0,46 & 0,55 & 1,37 & 0,28 \\
22 Olajos mag és olajos tartalmú & 2,17 & 2,25 & 8,32 & 2,30 & 2,36 \\
gyümölcs & & & & & \\
23 Nyersgumi & 0,02 & 0,39 & 0,33 & 0,01 & 0,56
\end{tabular}




\begin{tabular}{lccccc}
\hline Termékcsoport & $\begin{array}{c}\text { Világ- } \\
\text { piac }\end{array}$ & $\begin{array}{c}\text { Fejlett } \\
\text { országok }\end{array}$ & $\begin{array}{c}\text { Európai } \\
\text { Unió }\end{array}$ & $\begin{array}{c}\text { Fejlődő } \\
\text { országok }\end{array}$ & $\begin{array}{c}\text { Közép-európai } \\
\text { országok }\end{array}$ \\
\hline 24 Fa és parafa & 1,11 & 1,14 & 1,90 & 1,62 & 0,38 \\
26 Textilrost és hulladékai & 0,19 & 0,26 & 0,79 & 0,12 & 0,70 \\
29 Állati és növényi eredetü & 1,91 & 1,90 & 1,45 & 1,81 & 4,61 \\
nyersanyag & 1,22 & 0,97 & 1,61 & 3,62 & 2,96 \\
\hline 41 Állati olaj és zsír & 1,38 & 2,31 & 1,76 & 0,69 & 3,33 \\
42 Növényi olaj és zsír & 0,08 & 0,09 & 0,07 & 0,05 & 0,21 \\
43 Feldolgozott állati és növényi \\
olaj és zsír
\end{tabular}

Forrás: A szerző számításai az UNCTAD adatbázis alapján SITC rendszerben kétszámjegyü bontásban.

Megjegyzés: a besötétített számok azt mutatják, hogy melyik termékcsoportban nincs megnyilvánuló komparatív elöny.

A 2. táblázat árnyalja a magyar mezőgazdaság megnyilvánuló komparatív előnyeiről kialakított előbbi képünket. Az élelmiszerek és élólllatok esetében a halaknál egyik referenciacsoportban sincs komparatív előnyünk. A tej esetében csak a fejlődő országokban, a cukornál a fejlett országokban és az EU-ban, a kávénál a fejlett országokban és a közép-európai országokban, míg az állati takarmánynál a fejlett országokban, az EUban és a közép-európai országokban van komparatív előny. A tíz termékcsoportból csak ötben van mindegyik referenciapiacon megnyilvánuló komparatív előnye a magyar mezőgazdaságnak: az élőállat, a hús, a gabona, a zöldség és gyümölcs, valamint az egyéb táplálkozásra alkalmas termékek esetében.

A másik három nagyobb termékcsoport esetében is hasonló a helyzet. Az italok és a dohány közül az utóbbiban nincs komparatív előnyünk egyik piacon sem. A nyersanyagoknál a hat termékcsoportból kettőben van komparatív előny mindegyik referenciapiacon: az olajos magvak és az állati és növényi eredetü nyersanyagok esetében. Az állati és növényi olajoknál és zsíroknál nincs komparatív előny egyik piacon sem a feldolgozott állati és növényi olajok és zsírok esetében.

Összefoglalva, a kétszámjegyü bontásban a magyar agrárexport komparatív előnyei sokkal változékonyabbak a termékek és a referenciapiacok között, mint egyszámjegyű bontásban. Továbbá, míg magasabb aggregáltsági szinten a magyar mezőgazdaságnak a termékcsoportok és a referenciapiacok többségében komparatív elönye volt, addig a komparatív előnyökkel rendelkező termékek aránya mélyebb bontásban lényegesen alacsonyabb. 
3. táblázat

\section{A B-indexek átlaga termékcsoportonként és régióként 1992 és 2002 között háromszámjegyü bontásban}

\begin{tabular}{|c|c|c|c|c|c|}
\hline Termékcsoport & $\begin{array}{l}\text { Világ- } \\
\text { piac }\end{array}$ & $\begin{array}{c}\text { Fejlett } \\
\text { országok }\end{array}$ & $\begin{array}{l}\text { Európai } \\
\text { Unió }\end{array}$ & $\begin{array}{l}\text { Fejlődo” } \\
\text { országok }\end{array}$ & $\begin{array}{l}\text { Közép-európai } \\
\text { országok }\end{array}$ \\
\hline 001 élőállat & 3,57 & 3,23 & 2,86 & 5,40 & 3,22 \\
\hline 011 friss hús & 4,20 & 3,52 & 3,35 & 8,34 & 8,09 \\
\hline 012 szárított hús & 0,68 & 0,49 & 0,31 & 13,53 & 3,46 \\
\hline 014 feldolgozott hústermék & 6,97 & 7,03 & 4,90 & 8,20 & 4,89 \\
\hline 022 tej & 0,48 & 0,37 & 0,27 & 2,10 & 0,37 \\
\hline 023 vaj & 0,32 & 0,24 & 0,18 & 4,43 & 0,33 \\
\hline 024 sajt & 0,86 & 0,62 & 0,42 & 15,01 & 1,51 \\
\hline 025 tojás & 2,78 & 2,44 & 1,77 & 5,22 & 2,14 \\
\hline 034 friss hal & 0,10 & 0,11 & 0,16 & 0,07 & 0,15 \\
\hline 035 szárított hal & 0,00 & 0,00 & 0,00 & 0,00 & 0,00 \\
\hline 036 fagyasztott hal & 0,01 & 0,01 & 0,02 & 0,00 & 0,04 \\
\hline 037 feldolgozott haltermék & 0,00 & 0,00 & 0,00 & 0,00 & 0,00 \\
\hline 041 búza & 2,04 & 1,65 & 2,98 & 6,17 & 3,70 \\
\hline 042 rizs & 0,01 & 0,02 & 0,02 & 0,00 & 0,10 \\
\hline 043 árpa & 1,33 & 1,04 & 0,90 & 8,44 & 1,60 \\
\hline 044 kukorica & 4,29 & 4,02 & 9,10 & 5,48 & 11,92 \\
\hline 045 cereáliák & 1,99 & 1,61 & 3,20 & 4,92 & 3,92 \\
\hline 046 búzaliszt & 3,39 & 3,43 & 2,59 & 4,07 & 3,42 \\
\hline 047 egyéb liszt & 2,33 & 2,55 & 2,95 & 2,12 & 2,28 \\
\hline 048 feldolgozott cereáliák & 0,70 & 0,58 & 0,42 & 1,38 & 1,19 \\
\hline 054 friss zöldség & 1,64 & 1,72 & 1,33 & 1,40 & 2,67 \\
\hline 056 feldolgozott zöldség & 5,57 & 6,56 & 4,77 & 4,13 & 7,01 \\
\hline 057 friss gyümölcs & 0,77 & 0,98 & 0,85 & 0,46 & 2,72 \\
\hline 058 feldolgozott gyümölcs & 4,01 & 5,08 & 4,10 & 2,78 & 2,58 \\
\hline 061 cukor és méz & 0,94 & 1,55 & 1,16 & 0,47 & 0,96 \\
\hline 062 cukortermékek & 0,95 & 0,95 & 0,72 & 1,04 & 0,78 \\
\hline 071 kávé & 0,38 & 1,06 & 0,75 & 0,14 & 1,67 \\
\hline 072 kakaó & 0,02 & 0,04 & 0,03 & 0,01 & 0,29 \\
\hline 073 csokoládé & 1,45 & 1,13 & 0,80 & 6,31 & 1,66 \\
\hline 074 tea & 0,44 & 1,72 & 1,10 & 0,14 & 1,78 \\
\hline 075 füszerek & 2,43 & 7,95 & 5,72 & 0,83 & 5,49 \\
\hline 081 állati takarmány & 0,99 & 1,07 & 1,13 & 0,88 & 2,55 \\
\hline 091 margarin & 1,51 & 1,48 & 1,08 & 1,71 & 1,29 \\
\hline 098 egyéb termék & 2,14 & 1,82 & 1,57 & 3,86 & 3,27 \\
\hline 111 alkoholmentes italok & 2,16 & 2,01 & 1,45 & 2,82 & 2,33 \\
\hline 112 alkoholos italok & 1,53 & 1,22 & 0,79 & 4,54 & 1,83 \\
\hline 121 feldolgozatlan dohány & 0,21 & 0,32 & 0,50 & 0,11 & 0,33 \\
\hline
\end{tabular}




\begin{tabular}{|c|c|c|c|c|c|}
\hline Termékcsoport & $\begin{array}{l}\text { Világ- } \\
\text { piac }\end{array}$ & $\begin{array}{l}\text { Fejlett } \\
\text { országok }\end{array}$ & $\begin{array}{l}\text { Európai } \\
\text { Unió }\end{array}$ & $\begin{array}{l}\text { Fejlődő } \\
\text { országok }\end{array}$ & $\begin{array}{l}\text { Közép-európai } \\
\text { országok }\end{array}$ \\
\hline 122 feldolgozott dohány & 0,41 & 0,37 & 0,40 & 0,51 & 0,63 \\
\hline 211 nyersbőr & 0,63 & 0,55 & 0,74 & 1,38 & 0,32 \\
\hline 212 szőrme & 0,14 & 0,11 & 0,08 & 1,58 & 0,09 \\
\hline $\begin{array}{l}222 \text { olajos mag étkezési } \\
\text { olajhoz }\end{array}$ & 1,94 & 2,00 & 7,88 & 2,11 & 2,22 \\
\hline $\begin{array}{l}223 \text { olajos mag egyéb } \\
\text { olajhoz }\end{array}$ & 5,94 & 7,07 & 12,94 & 5,01 & 3,65 \\
\hline 232 nyersgumi & 0,02 & 0,39 & 0,33 & 0,01 & 0,56 \\
\hline $244 \mathrm{fa}$ & 0,01 & 0,00 & 0,00 & 0,01 & 0,22 \\
\hline 245 tüzifa & 14,41 & 41,10 & 37,67 & 7,82 & 2,69 \\
\hline 246 papírfa & 0,10 & 0,09 & 0,29 & 0,10 & 0,13 \\
\hline 247 egyéb fa & 2,00 & 2,81 & 5,68 & 2,77 & 0,40 \\
\hline 248 megmunkált fa & 0,76 & 0,71 & 1,13 & 1,38 & 0,32 \\
\hline 261 selyem & 0,00 & 0,00 & 0,00 & 0,00 & 0,00 \\
\hline 263 gyapot & 0,07 & 0,12 & 0,62 & 0,05 & 0,70 \\
\hline 264 juta & 0,00 & 0,00 & 0,00 & 0,00 & 0,03 \\
\hline 265 növényi rostok & 0,63 & 0,69 & 0,44 & 0,55 & 0,57 \\
\hline 268 gyapjú & 0,44 & 0,40 & 1,29 & 0,55 & 1,33 \\
\hline $\begin{array}{l}291 \text { állati eredetü } \\
\text { nyersanyag }\end{array}$ & 6,68 & 8,33 & 8,37 & 4,57 & 8,61 \\
\hline $\begin{array}{l}292 \text { növényi eredetü } \\
\text { nyersanyag }\end{array}$ & 0,76 & 0,72 & 0,53 & 0,80 & 2,39 \\
\hline 411 állati olaj és zsír & 1,22 & 0,97 & 1,61 & 3,62 & 2,96 \\
\hline 423 növényi olaj étkezési & 2,37 & 2,70 & 2,00 & 1,95 & 3,37 \\
\hline 424 egyéb növényi olaj & 0,08 & 0,28 & 0,26 & 0,03 & 3,70 \\
\hline $\begin{array}{l}431 \text { feldolgozott állati és } \\
\text { növényi olaj }\end{array}$ & 0,08 & 0,09 & 0,07 & 0,05 & 0,21 \\
\hline
\end{tabular}

Forrás: A szerző számításai az UNCTAD adatbázis alapján SITC rendszerben háromszámjegyú bontásban.

Megjegyzés: a besötétített számok azt mutatják, hogy melyik termékcsoportban nincs megnyilvánuló komparatív elöny.

A megnyilvánuló komparatív előnyök vizsgálata érdekesebbé válik, ha mélyebb bontású adatokat használunk. Magyarországnak 21 termékből van komparatív előnye a lehetséges 59 jószág közül mindegyik referenciapiacon, ugyanakkor 20 termékből egyik piacon sincs komparatív előnye (3. táblázat). A kétszámjegyű bontáshoz viszonyítva némi változást tapasztalunk a komparatív előnyök szerkezetében. A továbbiakban azokat a termékeket vizsgáljuk meg részletesebben, ahol komparatív előnye volt a magyar mezögazdaságnak magasabb aggregáltsági szinten. A hústermékeknél a szárított húsoknak, míg a gabonafélék esetében a rizsnek és a feldolgozott cereáliáknak nincs komparatív előnye három, illetve egyik piacon sem. Hasonló jelenséget tapasztalunk a zöldség és gyümölcs esetében, valamint az állati és növényi eredetű nyersanyagoknál, ahol nincs komparatív előnye négy referenciacsoportban a friss gyümölcsnek és a növényi eredetű nyersanyagoknak. 
A 3. táblázat módot ad arra is, hogy azonosítani tudjuk a lehetséges piaci réseket mind földrajzilag, mind termékcsoportok szintjén. A magyar mezőgazdaságnak a világpiacon, illetve a fejlett régiókban kevesebb számú termék esetében van komparatív előnye, mint a fejlődő országokban vagy a közép-európai országokban. Így például a szárított hús, a sajt és a feldolgozott cereáliák esetében komparatív előnyeink vannak a fejletlenebb régiókban, míg ennek a hiánya jellemző a fejlett országoknál és a világpiacon.

Röviden, a háromszámjegyü bontásban a magyar agrárexport komparatív elönyei hasonlóan változékonyak a termékek és a referenciapiacok között, mint kétszámjegyü bontásban. Továbbá, megerösítve a korábbi eredményeinket, míg magasabb aggregáltsági szinten a magyar mezőgazdaságnak a termékcsoportok többségében és a referenciapiacokon komparatív előnye volt, addig a mélyebb bontás felé haladva a komparatív előnyökkel rendelkezö termékek aránya egyre csökken.

\section{Az eloszlás dinamikája}

Az elemzést a B-index empirikus eloszlásának néhány jellemző tulajdonságával kezdjük. Az 1. ábrán a B-indexek átlagát láthatjuk az összes referenciapiacon. Az 1. ábra tanúsága szerint a B-indexek átlaga jelentős szóródást mutat az egyes referenciacsoportok között, azonban mindegyik esetében csökkenő trendet tapasztalhatunk. A visszaesés üteme különösen 1996-1999 között volt erős, utána a B-indexek átlagának értéke stabilizálódott. A vizsgált időszakban a B-indexek átlaga a fejlődő országok esetében volt a legmagasabb, míg a világpiacon a legalacsonyabb. Érdemes megjegyezni, hogy a B-inde-

1. ábra

A B-index átlaga 1992-2002 között

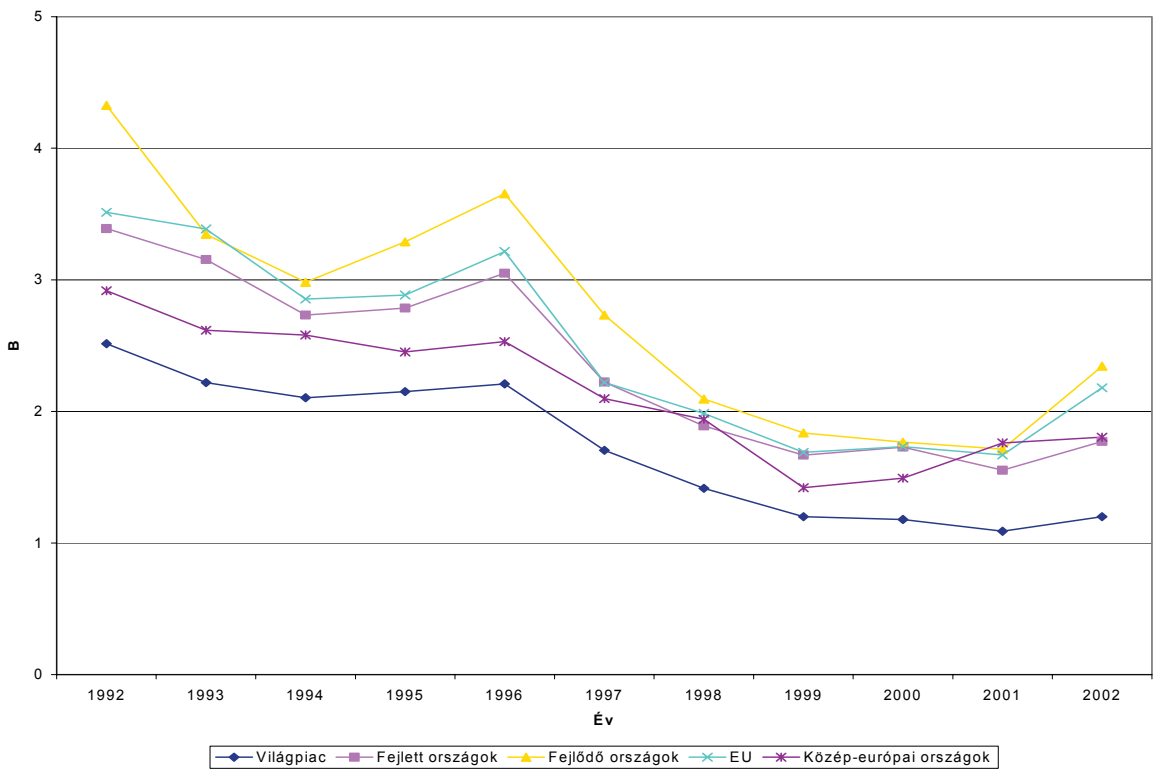

Forrás: A szerző számításai az UNCTAD adatbázis alapján SITC rendszerben háromszámjegyủ bontásban. 
xek átlagának legmagasabb és legalacsonyabb értéke közötti különbség csökkent, azaz a magyar agrártermékek B-indexeinek átlaga nagyobb mértékben esett vissza a fejlődő országokban, mint a világpiacon. Végül megállapíthatjuk, hogy 1992-2002 között a Bindexek átlaga mindegyik referenciacsoportban egynél magasabb volt.

A 2. ábra a B-indexek mediánját mutatja az összes referenciapiacon. Számításaink alapján a következő megfigyeléseket tehetjük. Egyrészt, a B-indexek mediánja mindegyik referenciacsoport esetében csökkent, különösen 1996-1999 között. Másrészt, a Bindexek mediánja az egész periódusban magasabb volt a közép-európai országok és a fejlődő országok esetében, mint a másik három piacon. Harmadszor, 1997-től a medián kisebb volt egynél a világpiacon, a fejlett országok és az EU esetében. Végezetül, 1999től a B-indexek mediánja mindegyik referenciacsoportnál egy alá esett. Másképpen fogalmazva, a kilencvenes évek végére a magyar agrárexportba kerülő termékeknek kevesebb, mint a felének volt megnyilvánuló komparatív előnye.

2. ábra

A B-index mediánja 1992-2002 között

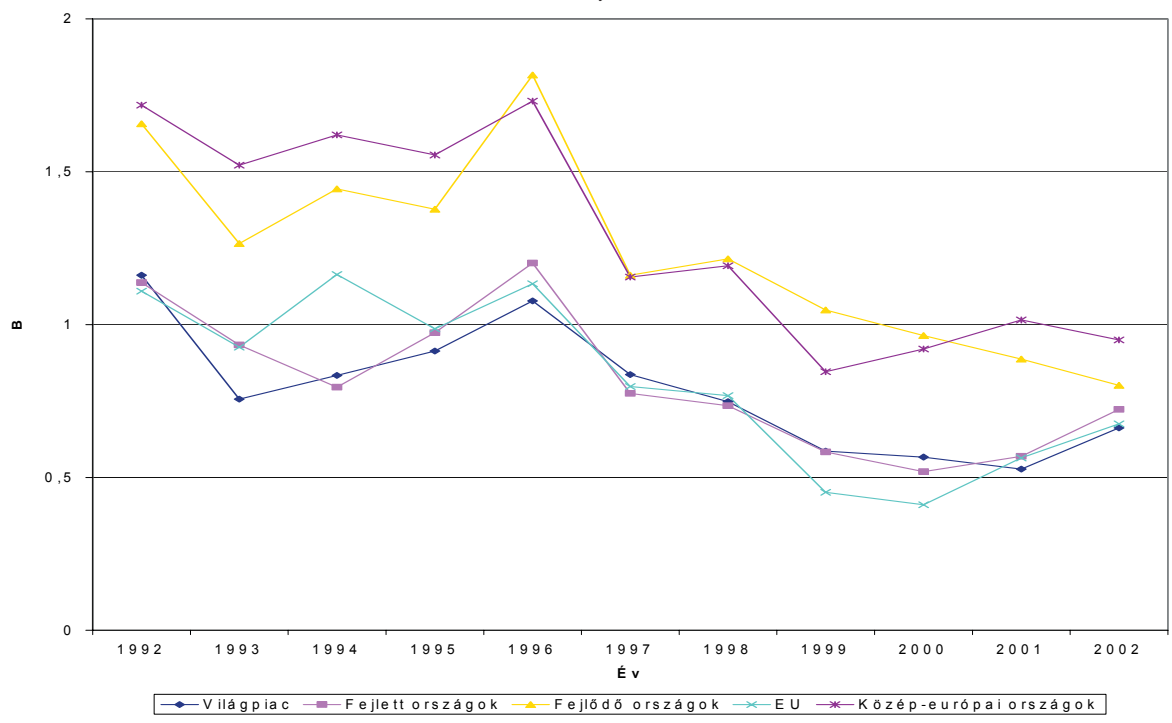

Forrás: A szerző számításai az UNCTAD adatbázis alapján SITC rendszerben háromszámjegyú bontásban.

A 3. ábra a megnyilvánuló komparatív előnyökkel rendelkező termékek $(B>1)$ arányát mutatja a teljes magyar agrárexportban, míg a 4. ábra az összes agrárterméken belüli hányadukat. A 3. ábra azt sugallja, hogy a magyar agrárexport 90 százaléka 1996-ig olyan termékekre specializálódott, amelyekből megnyilvánuló komparatív előnyei voltak hazánknak, bármely referenciacsoportot is nézzük. Ez az arány jelentősen csökkent a periódus végére, de még mindig 75 százalék fölött volt. A visszaesés dinamikája az egyes referenciacsoportokban azonban különböző volt 1997-1999 között, a fejlődő országokban és a közép-európai országokban kisebb, míg a fejlett régiókban nagyobb. Az utóbbiakban a komparatív előnnyel bíró termékek aránya közel 10 százalékot emelkedett az utolsó három évben. 


\section{A B >1 termékek aránya a magyar agrárexportban 1992-2002 között}

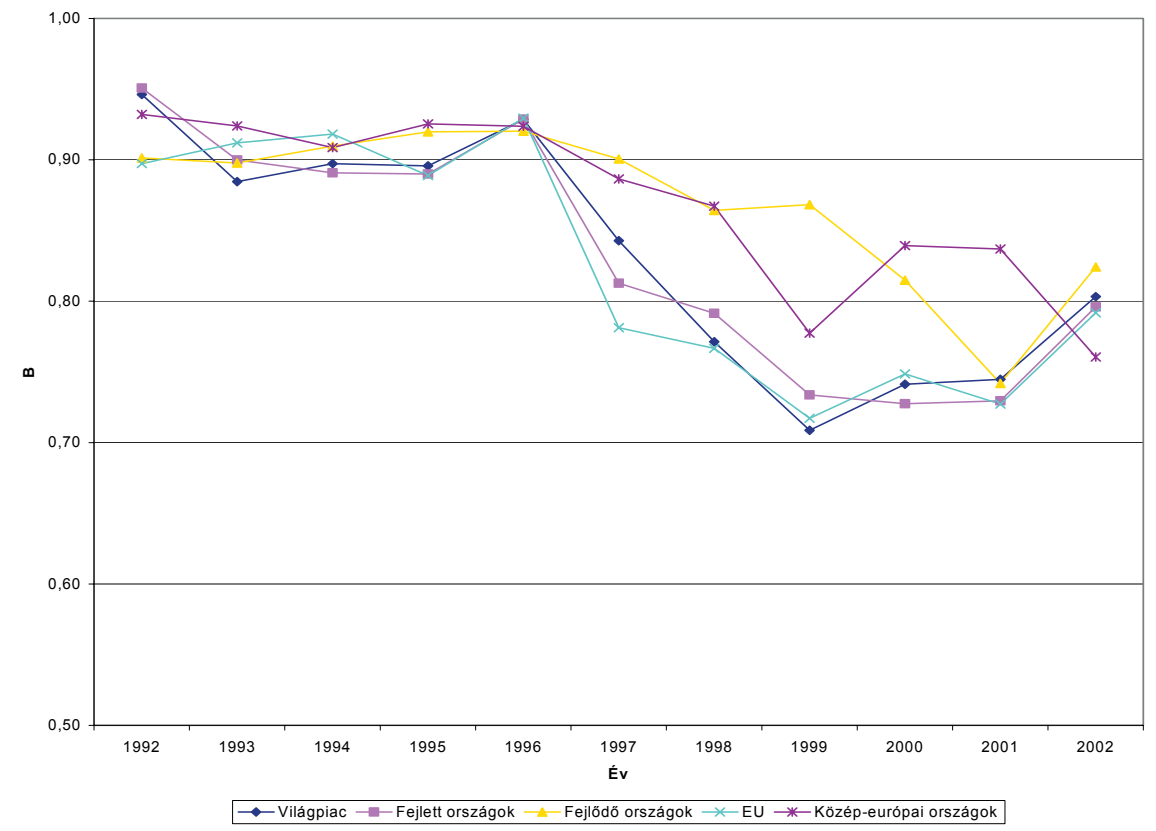

Forrás: A szerző számításai az UNCTAD adatbázis alapján SITC rendszerben háromszámjegyü bontásban.

A 4. ábra hasonló képet mutat. A megnyilvánuló komparatív előnyökkel rendelkező termékcsoportok száma minden referenciacsoportban csökkenő tendenciát mutat. Az egyes régiók ebben az esetben is jelentős szóródást mutatnak. A fejlődő országokban és a közép-európai országokban az egész periódusban magasabb volt a megnyilvánuló komparatív előnyökkel bíró termékek száma, arányuk az összes mezőgazdasági termékcsoporton belül 60 százalékról 50 százalék alá esett. A világpiacon, a fejlett országokban és az EU-ban ez a hányad 50 százalékról 40 százalék alá süllyedt. A visszaesés üteme itt is 1996 és 1999 között volt a legerőteljesebb. Fontos megjegyezni, hogy a megnyilvánuló komparatív előnyökkel rendelkező termékek számának aránya az összes agrárterméken belül alacsonyabb, mint amekkora súlyt képviselnek ezek a jószágok a teljes agrárexportban. 
4 ábra

A B>1 termékek számának aránya az összes agrártermékben 1992-2002 között

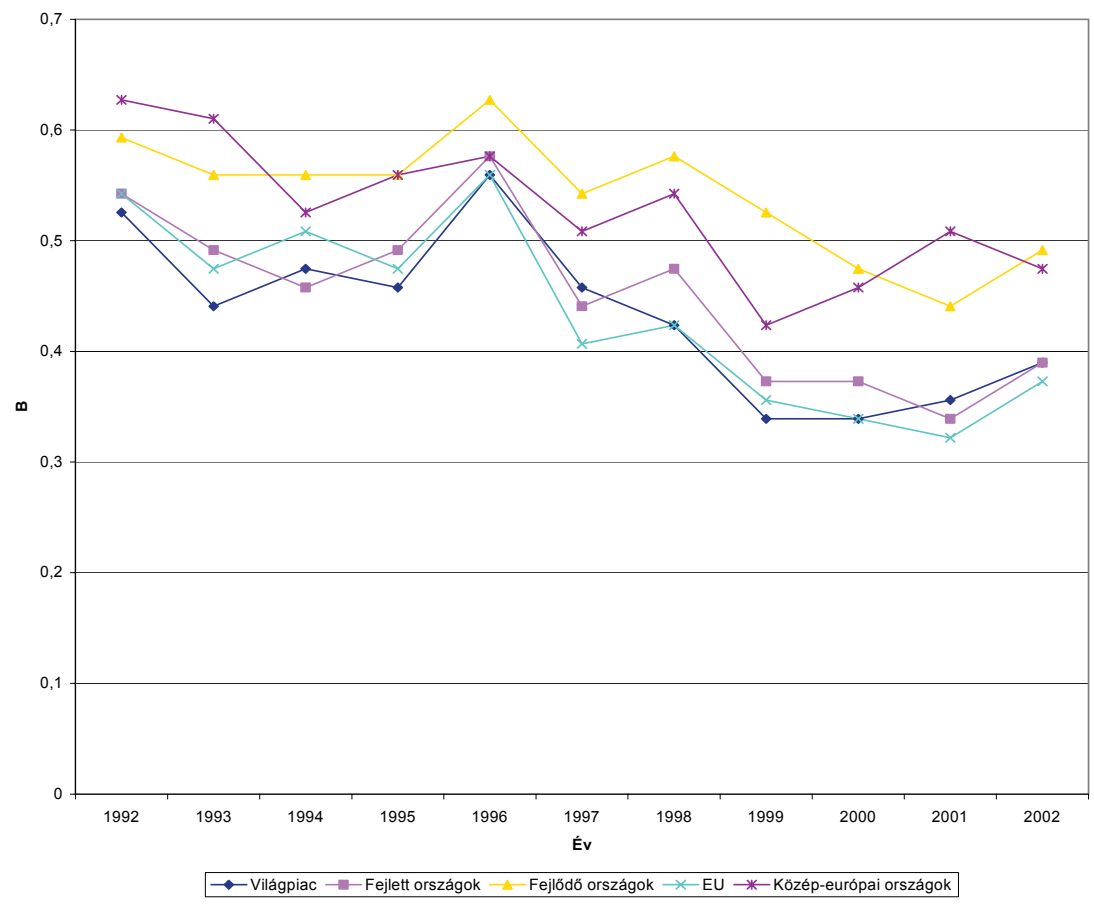

Forrás: A szerző számításai az UNCTAD adatbázis alapján SITC rendszerben háromszámjegyü bontásban.

Teljesebb képet kaphatunk, ha a Balassa-indexek szektorális eloszlását vizsgáljuk meg. $\mathrm{Az}$ 5. ábra a Balassa-mutatók Kernel-féle sürüségfüggvényeit mutatja minden egyes referenciacsoportra a vizsgálat minden egyes évében. A Kernel-féle sürűségfüggvények eloszlása aszimmetrikus és jobbra elnyúló. Ellentétben Hinloopen - van Marrewijk (2001) várakozásaival az eloszlások nem monoton csökkenők egyik esetben sem. A Kernel-féle sürüségfüggvények eloszlása arra utal, hogy a nulla alatti szektorok száma megnövekedett a periódus végére, azaz a magyar mezőgazdaság az összes referenciapiacon elveszítette komparatív előnyeit számos agrártermék esetében. Ez megerősíti a Balassa-indexek 3. és 4. ábrán alapuló számításaink eredményét. A Kernel-féle sürüségfüggvények jobbra tolódásának a hiánya azt mutatja, hogy a vizsgált periódusban nem növekedett a specializáció. 
5. ábra

A Balassa-indexek Kernel-féle sürüségfüggvényei különböző referenciacsoportok esetében
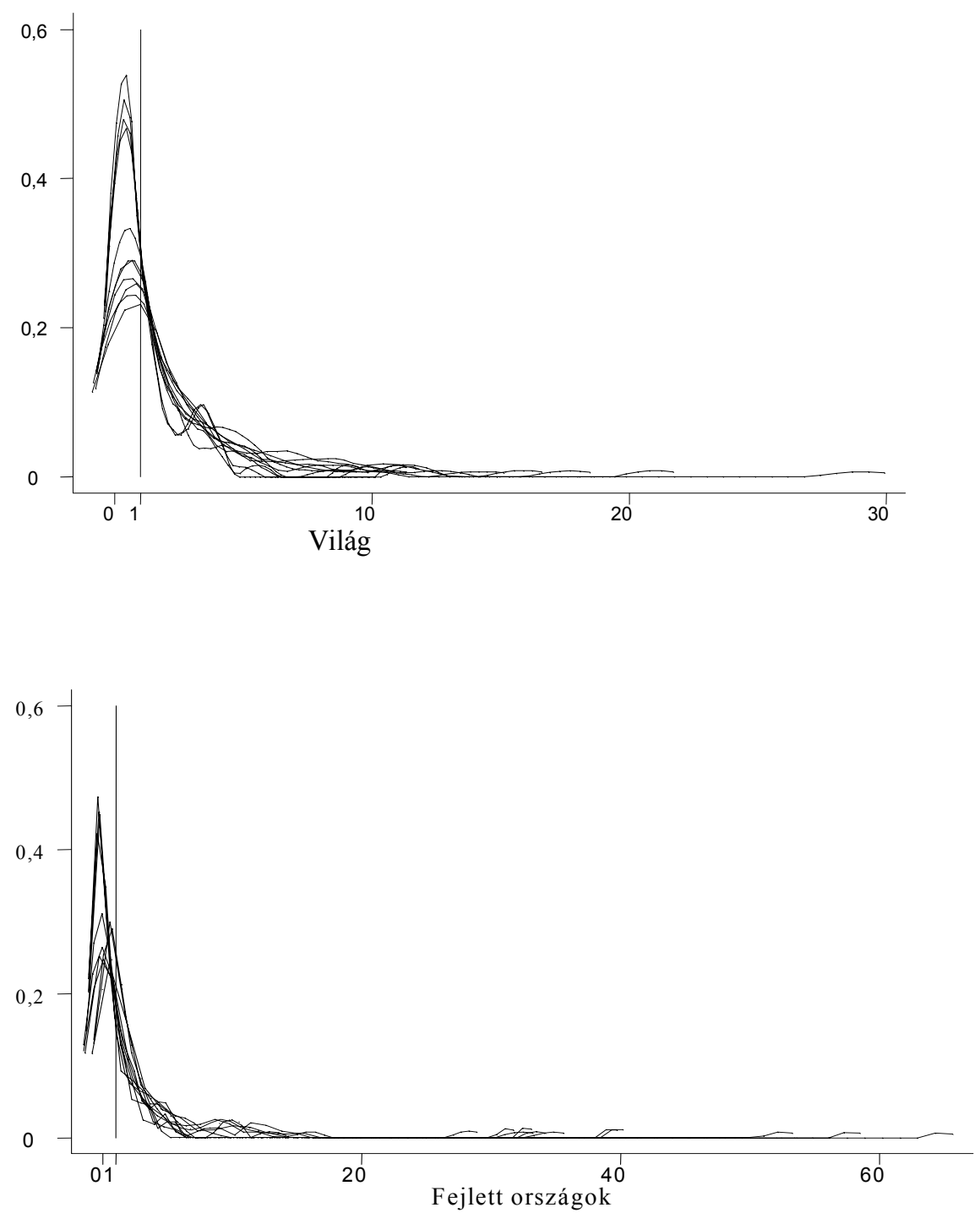

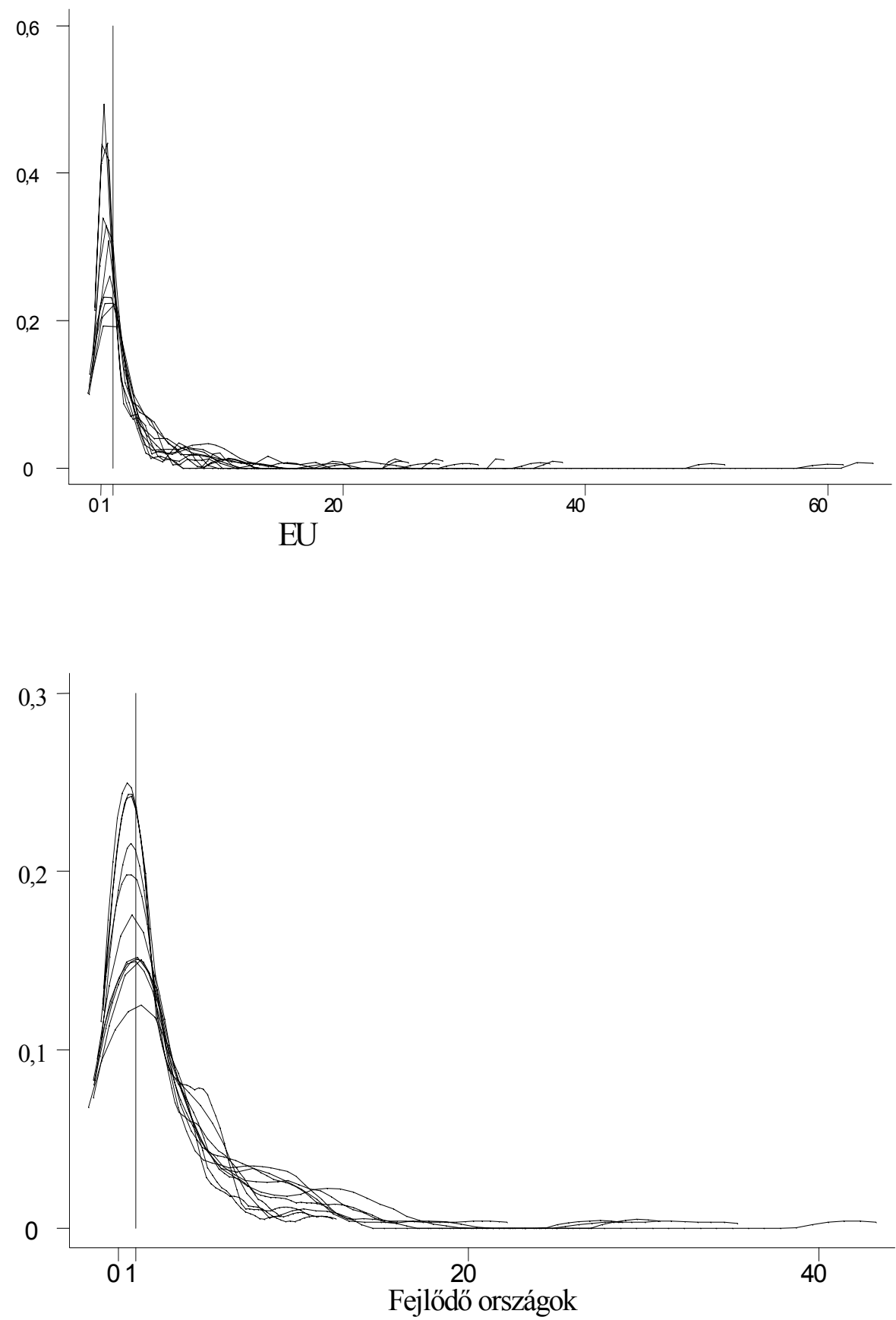


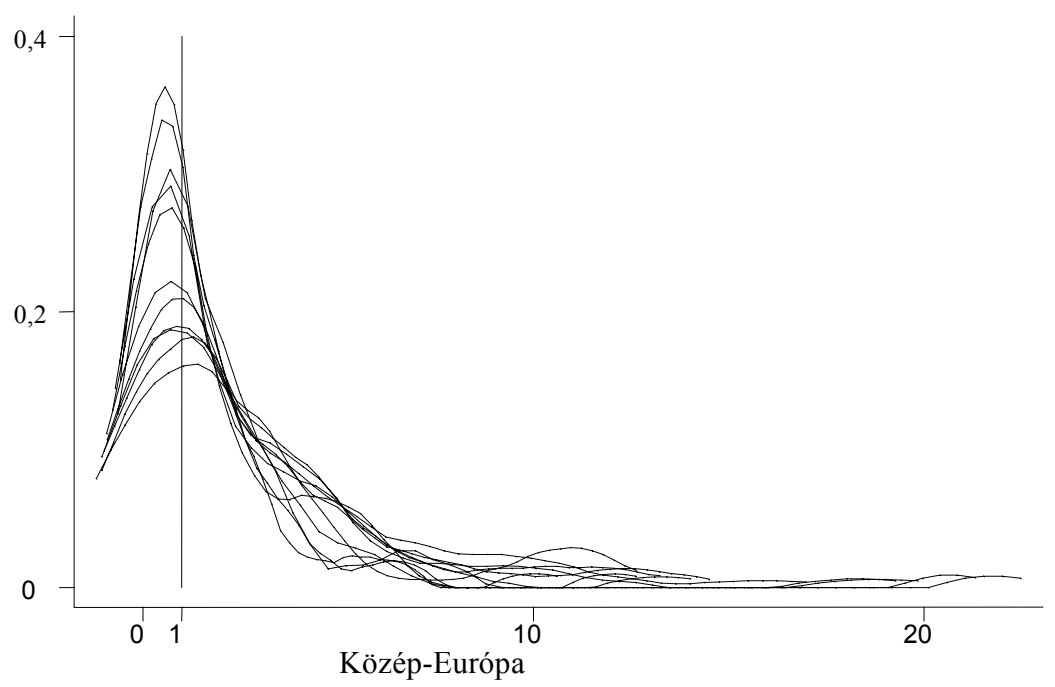

Forrás: A szerző számításai az UNCTAD adatbázis alapján SITC rendszerben háromszámjegyủ bontásban.

4. táblázat

A kétoldalú Wilcoxon-féle rangösszeg próbájának p értékei (bázis év=2002)

\begin{tabular}{lccccc}
\hline & Világpiac & $\begin{array}{c}\text { Fejlett } \\
\text { országok }\end{array}$ & EU & Fejlödő országok & $\begin{array}{c}\text { Közép-európai } \\
\text { országok }\end{array}$ \\
\hline 1992 & 0,000 & 0,000 & 0,000 & 0,003 & 0,001 \\
1993 & 0,000 & 0,000 & 0,003 & 0,089 & 0,001 \\
1994 & 0,000 & 0,000 & 0,008 & $\mathbf{0 , 1 2 7}$ & 0,006 \\
1995 & 0,000 & 0,000 & 0,001 & 0,031 & 0,017 \\
1996 & 0,000 & 0,000 & 0,000 & 0,035 & 0,004 \\
1997 & 0,002 & 0,001 & 0,046 & $\mathbf{0 , 5 1 9}$ & $\mathbf{0 , 1 4 3}$ \\
1998 & 0,002 & 0,001 & 0,063 & $\mathbf{0 , 6 7 1}$ & $\mathbf{0 , 7 9 0}$ \\
1999 & $\mathbf{0 , 5 9 8}$ & $\mathbf{0 , 9 6 7}$ & $\mathbf{0 , 1 2 7}$ & $\mathbf{0 , 1 5 9}$ & $\mathbf{0 , 1 1 1}$ \\
2000 & $\mathbf{0 , 2 9 5}$ & $\mathbf{0 , 1 1 3}$ & 0,004 & $\mathbf{0 , 1 3 2}$ & $\mathbf{0 , 5 5 8}$ \\
2001 & 0,018 & 0,004 & 0,024 & 0,024 & $\mathbf{0 , 8 5 4}$ \\
\hline
\end{tabular}

Forrás: A szerző számításai az UNCTAD adatbázis alapján SITC rendszerben háromszámjegyü bontásban. Megjegyzés: a félkövér számok a nullhipotézis elvetését mutatják 10 százalékos szignifikanciaszinten.

Annak érdekében, hogy értékelni tudjuk a jelzett változások statisztikai szignifikanciáját, kétoldalú Wilcoxon-féle rangösszeg próbát hajtottunk végre. A nullhipotézis az volt, hogy nincs eltérés a vizsgálat utolsó éve (2002) és azt megelőző évek B-indexeinek eloszlása között. Eredményeink azt mutatták, hogy az ötven lehetséges teszt közül tizenöt esetében 10 százalékos konfidencia szinten elvethetjük azt a hipotézist, hogy a B-indexek eloszlása változatlan maradt (4. táblázat). Érdekes módon a B-indexek 2002. évi eloszlása nem változott a vizsgálat első két évéhez viszonyítva. A B-indexek eloszlásában megfigyelhető változások döntő hányada a fejlődő és a közép-európai országokra koncentrálódik az 1997 utáni időszakban. 


\section{Az eloszláson belüli dinamika}

$\mathrm{Az}$ irodalomban alapvetően két eljárás terjedt el az adatok kezelésére a (2) egyenlethez hasonló regressziós modellek becslésében. Az első megoldás, amikor két időpont adatait hasonlítjuk össze, például a periódus első és utolsó évét. A másik módszer, amikor adatainkból kombinált keresztmetszeti és idősoros (pooled) adatbázist készítünk, majd ezt követően különböző idejü késleltetéssel becsüljük meg a (2) egyenletet. A két eljárás eredménye megegyezik, ha a második módszerrel csak a kezdő és az utolsó évet hasonlítjuk össze. Mivel a perióduson belüli dinamikára is kíváncsiak vagyunk, ezért a kombinált adatbázis használata tünik célszerünek (pl. Hinloopen - van Marrewijk 2004a). Miután nincs általánosan elfogadott eljárás az irodalomban a késleltetés hoszszának megválasztására, ezért az összes lehetséges késleltetési időtartamra (egytől tíz évig) megbecsültük a modellünket. A (2) egyenleten alapuló regressziós eredményeket az 5. tábla mutatja. Mivel nehézkes lenne az ötven regressziós modell eredményeinek a bemutatása, ezért illusztrációként csak az egy és a tíz év késleltetés melletti számításokat ismertetjük.

5. táblázat

A Balassa-indexek stabilitása 2002 és 1992 között

\begin{tabular}{lccccc}
\hline & $\beta$ & P érték & $\mathrm{R}^{2}$ & $\beta / \mathrm{R}$ & $\mathrm{N}$ \\
\hline Egy éves késleltetés & & & & & \\
Világpiac & 0,807 & 0,000 & 0,823 & 0,889 & 590 \\
Fejlett országok & 0,872 & 0,000 & 0,886 & 0,927 & 590 \\
Európai Unió & 0,848 & 0,000 & 0,830 & 0,931 & 590 \\
Fejlödő országok & 0,651 & 0,000 & 0,531 & 0,894 & 590 \\
Közép-európai országok & 0,722 & 0,000 & 0,563 & 0,962 & 590 \\
& & & & & \\
Tíz éves késleltetés & & & & & 59 \\
Világpiac & 0,370 & 0,000 & 0,866 & 0,398 & 59 \\
Fejlett országok & 0,590 & 0,000 & 0,957 & 0,603 & 59 \\
Európai Unió & 0,614 & 0,000 & 0,929 & 0,637 & 59 \\
Fejlődő országok & 0,248 & 0,000 & 0,304 & 0,450 & 59 \\
Közép-európai országok & 0,394 & 0,000 & 0,328 & 0,688 & \\
\hline
\end{tabular}

Forrás: A szerző számításai az UNCTAD adatbázis alapján SITC rendszerben háromszámjegyű bontásban.

A regressziós együttható minden esetben szignfikánsan nagyobb nullánál és kisebb egynél, ami arra utal, hogy elvethetjük azt a hipotézist, hogy a magyar agrárkereskedelem szerkezete véletlenszerüen vagy fordított irányban változott meg. Vizsgálatunk azt mutatja, hogy a kereskedelem szerkezete nem módosult jelentősen, ha csak egy éves késleltetést alkalmazunk. A számítások azonban nagyobb változásokra utalnak a Balassaindex eloszlásában a kezdő és az utolsó év között. A $\beta / R$ arányok azt mutatják, hogy a megnyilvánuló komparatív előnyök szerkezete konvergált, függetlenül a választott késleltetés időtartamától (6. ábra). Továbbá láthatjuk, hogy a késleltetés hosszának növelésével a $\beta / R$ arányok is folyamatosan csökkennek, ami a konvergencia erősödésére utal. 


\section{A $\beta /$ r arány különböző idejü késleltetéseknél}

6. ábra

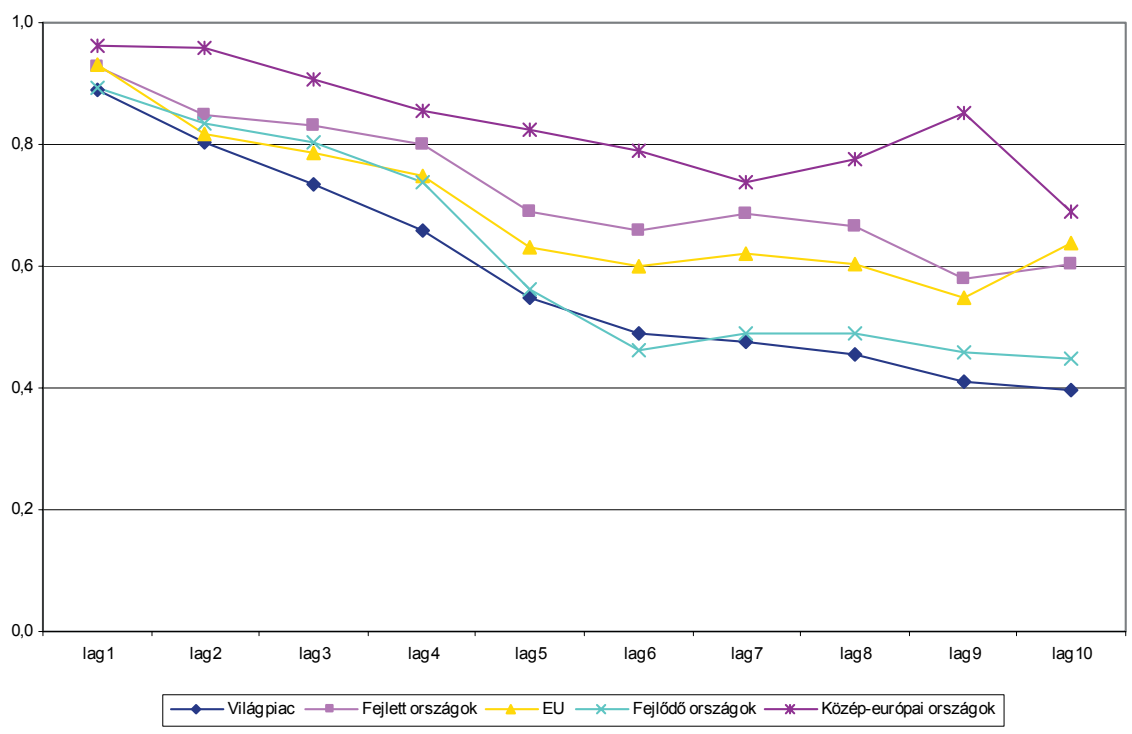

Forrás: A szerző számításai az UNCTAD adatbázis alapján SITC rendszerben háromszámjegyü bontásban.

A 7. ábra a Gini-indexek alakulását mutatja az egyes referenciacsoportokban 1992 és 2002 között. Láthatjuk, hogy a magyar agrárexport specializációja a fejlett országok és az EU specializációjához viszonyítva tér el leginkább, míg a specializációban meglévő különbségek a világpiac, a fejlődő országok és a közép-európai országok esetében lényegesen kisebbek.

A Gini-együtthatók logaritmusa és az időtrend között regressziós elemzést végeztünk, hogy pontosabb képet kapjunk a magyar agrárexport specializációjának időbeli alakulásáról az egyes referenciapiacokon. Eredményeink tanúsága szerint a hazai agrárexport specializációja szignifikánsan csökkent a világpiachoz és a fejlődő országokhoz viszonyítva (6. táblázat). A közép-európai országokhoz képest viszont emelkedett a magyar mezőgazdasági export specializációja, míg a másik két referenciapiachoz viszonyítva nem találtunk szignifikáns változást. 
A B-indexek Gini-együtthatói 1992-2002 között

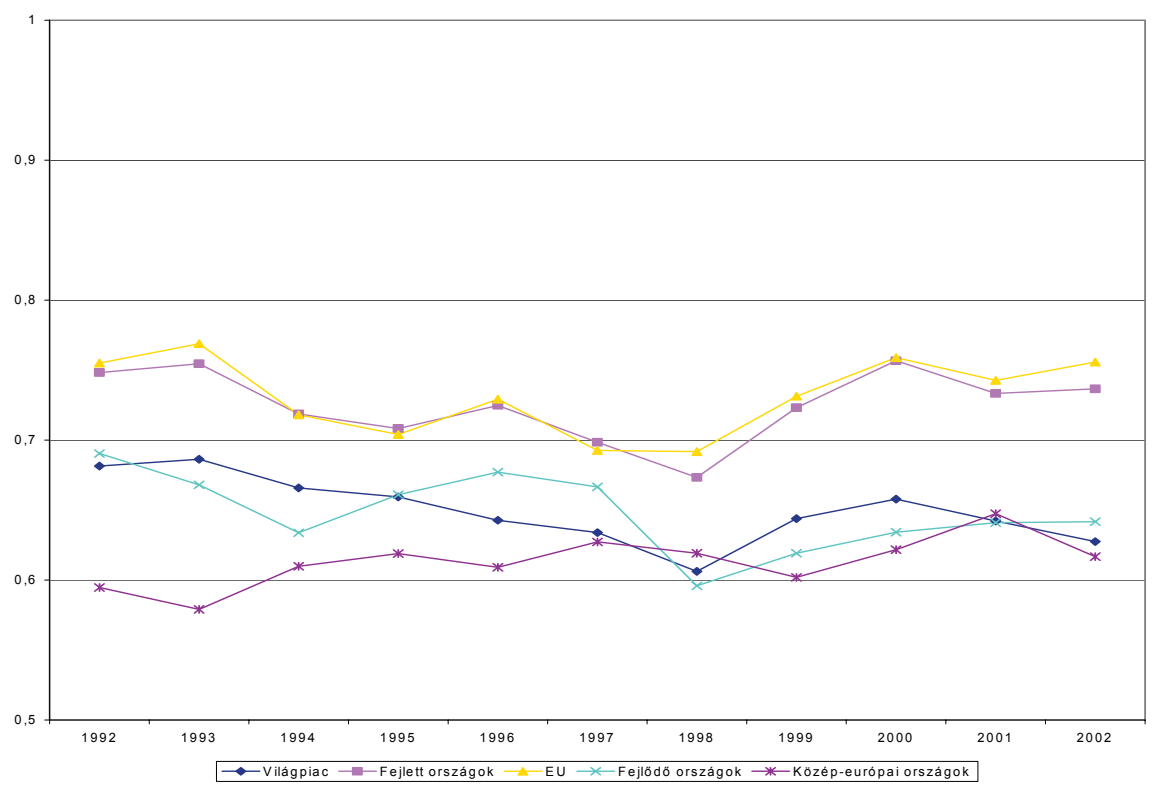

Forrás: A szerző számításai az UNCTAD adatbázis alapján SITC rendszerben háromszámjegyü bontásban.

A Gini-együtthatókon alapuló regressziós eredmények

6. táblázat

\begin{tabular}{lcccc}
\hline & $\beta$ & $\mathrm{p}$ & $\mathrm{R}^{2}$ & $\mathrm{~N}$ \\
\hline \multicolumn{1}{c}{ Világ } & $-0,007$ & 0,021 & 0,463 & 11 \\
Fejlett országok & $-0,001$ & 0,861 & 0,004 & 11 \\
Európai Unió & 0,001 & 0,896 & 0,002 & 11 \\
Fejlödö országok & $-0,007$ & 0,077 & 0,308 & 11 \\
Közép-Kelet-Európa & 0,006 & 0,024 & 0,448 & 11 \\
\hline
\end{tabular}

Forrás: A szerző számításai az UNCTAD adatbázis alapján SITC rendszerben háromszámjegyű bontásban.

\section{Az eloszláson belüli dinamika}

További információkat szerezhetünk a kereskedelmi indexek dinamikájáról a Markov átmeneti mátrixok elemzésének segítségével. Az általunk becsült átmenet-valószínüségi mátrix egy tizenegy éves perióduson alapul, és a valószínűségeket hasonlítja össze közvetlenül - azaz egyik állapotból a másikba való kerülés relatív gyakoriságát - a kezdő év (1992) és a záró év (2002) között. Hasonlóan a regressziós elemzéshez itt is kombinált adatokat használtunk, amelyeket különböző idejű késleltetésekkel becsültünk meg. Mivel az öt referenciapiacon tíz különböző késleltetést alkalmaztunk, ezért összesen ötven valószínűségi átmeneti mátrixot kaptunk. Az eredmények könnyebb áttekinthe- 
tősége érdekében, ezért kiszámítottuk a lehetséges tíz valószínüségi átmeneti mátrix átlagát minden referenciacsoportban. Eredményeinket a 7. táblázat mutatja.

\section{A Balassa-indexek valószínüségi átmeneti mátrixainak átlaga}

Világpiac

\begin{tabular}{ccccc}
\hline $\mathrm{B}$ & $\mathrm{a}$ & $\mathrm{b}$ & $\mathrm{c}$ & $\mathrm{d}$ \\
\hline $\mathrm{a}$ & 0,92 & 0,05 & 0,02 & 0,00 \\
$\mathrm{~b}$ & 0,56 & 0,33 & 0,09 & 0,02 \\
$\mathrm{c}$ & 0,21 & 0,44 & 0,31 & 0,04 \\
$\mathrm{~d}$ & 0,04 & 0,11 & 0,46 & 0,39 \\
\hline
\end{tabular}

Fejlett országok

\begin{tabular}{ccccc}
\hline B & $\mathrm{a}$ & $\mathrm{b}$ & $\mathrm{c}$ & $\mathrm{d}$ \\
\hline $\mathrm{a}$ & 0,92 & 0,06 & 0,02 & 0,00 \\
$\mathrm{~b}$ & 0,55 & 0,35 & 0,07 & 0,02 \\
$\mathrm{c}$ & 0,23 & 0,41 & 0,34 & 0,02 \\
$\mathrm{~d}$ & 0,05 & 0,06 & 0,39 & 0,50 \\
\hline
\end{tabular}

Európai Unió

\begin{tabular}{ccccc}
\hline B & a & b & $c$ & d \\
\hline a & 0,92 & 0,04 & 0,03 & 0,01 \\
$\mathrm{~b}$ & 0,61 & 0,31 & 0,07 & 0,01 \\
$\mathrm{c}$ & 0,30 & 0,26 & 0,38 & 0,06 \\
$\mathrm{~d}$ & 0,03 & 0,08 & 0,36 & 0,54 \\
\hline
\end{tabular}

Fejlődő országok

\begin{tabular}{ccccc}
\hline B & $\mathrm{a}$ & $\mathrm{b}$ & $\mathrm{c}$ & $\mathrm{d}$ \\
\hline $\mathrm{a}$ & 0,93 & 0,02 & 0,05 & 0,00 \\
$\mathrm{~b}$ & 0,39 & 0,39 & 0,15 & 0,07 \\
$\mathrm{c}$ & 0,17 & 0,32 & 0,31 & 0,20 \\
$\mathrm{~d}$ & 0,05 & 0,09 & 0,34 & 0,52 \\
\hline
\end{tabular}

Közép-európai országok

\begin{tabular}{ccccc}
\hline B & a & b & c & d \\
\hline a & 0,87 & 0,06 & 0,03 & 0,04 \\
b & 0,46 & 0,30 & 0,17 & 0,07 \\
c & 0,21 & 0,33 & 0,36 & 0,10 \\
d & 0,12 & 0,16 & 0,30 & 0,42 \\
\hline
\end{tabular}

Forrás: A szerző számításai az UNCTAD adatbázis alapján SITC rendszerben háromszámjegyü bontásban. 
A valószínűségi átmeneti mátrixok a 7. táblázatban azt sugallják, hogy az egynél kisebb B-indexủ megfigyelések (azaz a megnyilvánuló komparatív hátrány) meglehetősen stabilnak bizonyultak mindegyik referenciacsoportban ( $a$ osztály) 1992 és 2002 között. Ebben az osztályközben az átlóban lévő elemek értéke 0,87 vagy magasabb mindegyik referenciapiacon, ami arra utal, hogy ha egy terméknek megnyilvánuló komparatív hátránya van a periódus elején, akkor nagy valószínüséggel ebben a státuszban marad az időszak végén is. A $b$, $c$ és $d$ osztályban lévő indexek azonban lényegesen nagyobb változékonyságot mutatnak. A komparatív előny elvesztésének valószínűsége a gyenge megnyilvánuló komparatív előnnyel rendelkező megfigyelések ( $b$ osztály) esetében ötven százalék fölött van a világpiacon és a fejlett régiókban, míg ez az arány legalább 10 százalékkal alacsonyabb a fejlődő országok és a közép-európai országok esetében. Hat százalék vagy annál kisebb a valószínűsége a $c$ osztályból (közepes komparatív előny) a $d$ osztályba (erős komparatív előny) való kerülésnek a világpiac, a fejlett országok és az EU esetében. Az erős komparatív előnnyel rendelkező termékek 5 százalék alatti az esélyük, hogy teljesen elveszítsék a komparatív előnyeiket, kivéve a közép-európai országokat, ahol ez az arány némileg magasabb (12 százalék). Összefoglalva, az eredmények arra utalnak, hogy míg a Balassa-indexeknek jelentős esélyük van az alacsonyabb értékủ csoportokba való kerülésre, addig csak kevés esélyük van helyzetük javítására.

8. ábra

Az M1 indexek különböző idejü késleltetések mellett

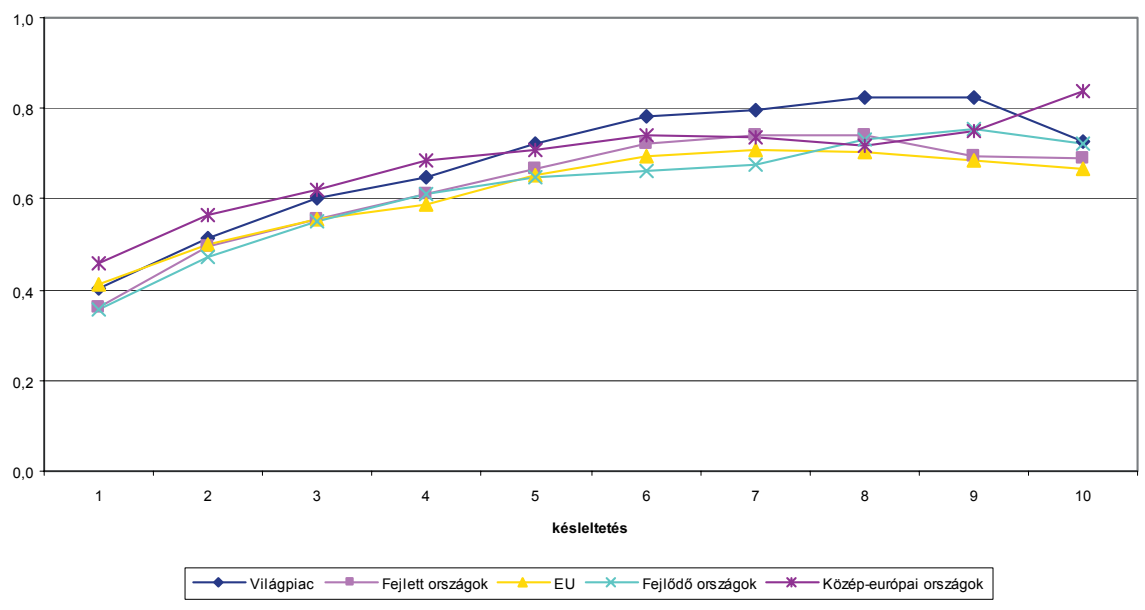

Forrás: A szerző számításai az UNCTAD adatbázis alapján SITC rendszerben háromszámjegyü bontásban.

A 8. és a 9. ábra mutatja a mobilitási indexeket, $M_{1}$ és $M_{2}$, mindegyik referenciacsoportra különböző idejű késleltetések mellett. Mindkét index szerint a mobilitás csökkenése figyelhető meg a késleltetés idejének egyidejű növelésével, bár az $M_{2}$, index értéke öt év késleltetés után stabilizálódik. Ez arra utal, hogy a magyar agrárkereskedelem szerkezete rövid távon lényegesen stabilabb, mint hosszabb távon, függetlenül a referenciapiacoktól. Meg kell jegyezni azonban, hogy a két index nem eredményez konzisztens rangsort az országok között. 
9. ábra

Az M2 indexek különböző idejü késleltetések mellett

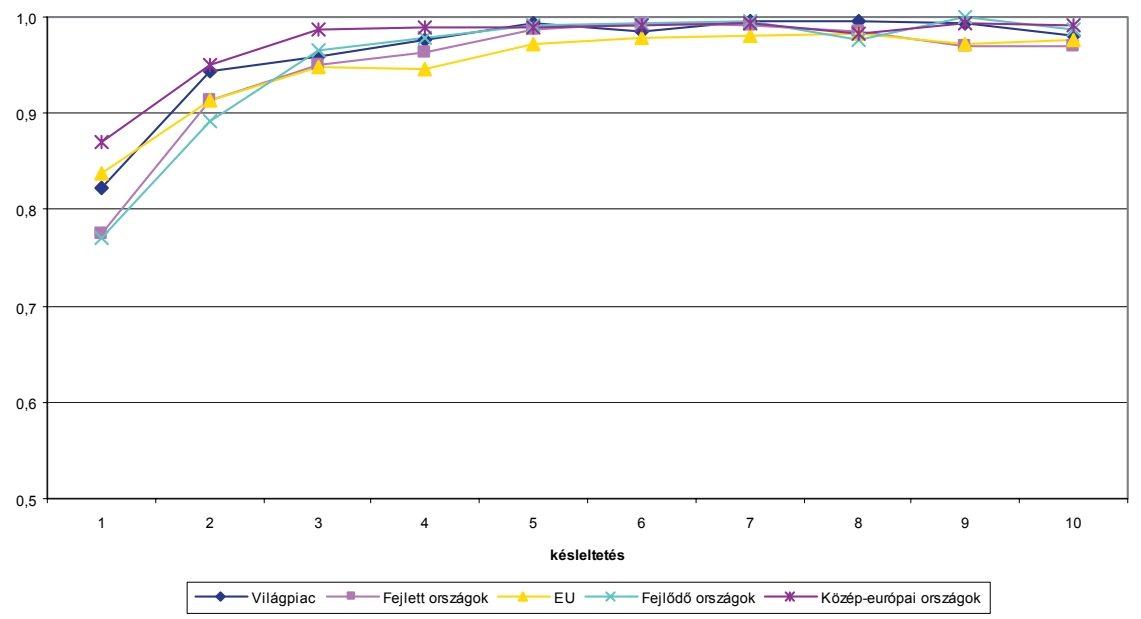

Forrás: A szerző számításai az UNCTAD adatbázis alapján SITC rendszerben háromszámjegyü bontásban.

\section{Összefoglalás és következtetések}

Tanulmányunkban a magyar agrárkereskedelem szerkezetének dinamikáját vizsgáltuk meg 1992 és 2002 között öt különböző referenciapiacon és három különböző aggregáltsági szinten. A kereskedelem specializációjának mérésére a klasszikus Balassaindexet használtuk. A magyar mezőgazdaságban lezajlott jelentős változások ellenére a B-indexek eloszlása meglehetősen stabilnak bizonyult. A magyar agrárkereskedelem egy csökkenő specializáció trendjét mutatja mindegyik referenciacsoportban. Más szavakkal, hazánk elveszítette komparatív előnyeit számos termékcsoportban, függetlenül a vizsgált referenciapiactól. A B-indexek közelebbi vizsgálata azt mutatja, hogy azok konvergáltak egymáshoz a vizsgált időszakban. Az érzékenységi elemzés azt mutatta, hogy a magyar agrárexport szerkezete rövidebb távon stabilabb, mint hosszabb távon. Eredményeink tanúsága szerint a hazai agrárexport specializációja szignifikánsan csökkent a világpiachoz és a fejlődő országokhoz viszonyítva, míg a közép-európai országokhoz képest emelkedett. A B-indexek stabilitása az egyes termékcsoportok szintjén már kevésbé mutatott állandóságot. Az átmeneti mátrixok elemzése azt sugallja, hogy meglehetősen nagy annak a valószínủsége, hogy egy termékcsoport specializációja csökkenjen, míg annak növekedésére alig van esély. Továbbá, hogy az egyes termékcsoportok mobilitása az idő elörehaladtával növekszik.

\section{Hivatkozások}

Amiti, M. (1998): New Trade Theories and Inudstrial Location in the EU. A Survey of Evidence. Oxford Review of Economic Policy, 14/2. sz. 45-53.

Amiti, M. (1999): Specialization Patterns in Europe. A Survey of Evidence. Weltwirtschaftliches Archiv, 135/4. sz. 573-593. 
Balassa, B. (1965): Trade Liberalization and Revealed Comparative Advantage. The Manchester School of Economic and Social Studies, 33/1. sz. 99-123.

Brasili, A. - Epifani, P. - Helg, R. (2000): On the Dynamics of Trade Patterns. De Economist, 148/2. sz. 233-257.

Cantwell, J. (1989): Technological Innovation and Multinational Corporations. Blackwell, Oxford.

Dalum, B. - Laursen, K. - Villumsen, G. (1998): Structural Change in OECD Export Specialisation Patterns: De-Specialisation and 'Stickiness'. International Review of Applied Economics, 12/3. sz. 423-443.

Fertő, I. (2003b): A komparatív elönyök mérése. Statisztikai Szemle, 81. évf. 4.sz. 309-327.

Fertő, I. (2003a): A magyar agrárkereskedelem dinamikájáról. Competitio, 2. évf. 1. sz. 26-35.

Fertö, I. (2004): The Agri-Food Trade between Hungary and the EU. Századvég Kiadó, Budapest.

Fertő, I. - Hubbard, L. J. (2003): Revealed Comparative Advantage and Competitiveness in Hungarian Agri-Food Sectors. World Economy, 26/2. sz. 247-259.

Fertő, I. - Hubbard, L. J. (2005): Az agrárkereskedelem dinamikája - A csatlakozó országok esete. Közgazdasági Szemle 51. évf. 1. sz. 77-89.

Geweke, J. - Marshall, R. - Zarkin, G. (1986): Mobility indices in continuous time Markov chains. Econometrica, 54. évf. 1407-1423.

Hinloopen, J. - van Marrewijk, C. (2001): On the Emprical Distribution of the Balassa Index. Weltwirtschaftliches Archiv, 137/1. sz. 1-35.

Hinloopen, J. - van Marrewijk, C. (2004): Empirical relevance of the Hillman condition and the comparative advantage. Tinbergen Institute Discussion Paper, 019/2. Tinbergen Institute, Amsterdam.

Hinloopen, J. - van Marrewijk, C. (2004a): Dynamics of Chinese Comparative Advantage. Tinbergen Institute Discussion Paper, 034/2. Tinbergen Institute, Amsterdam.

Lange, D. (1989): Economic Development and Agricultural Trade Pattern: An Empirical Cross-Country Analysis. European Review of Agricultural Economics, 16/2. sz. 187-202.

Laursen, K. (2000): Trade Specialisation, Technology and Economic Growth. Edward Elgar, Cheltenham.

Proudman, J. - Redding, S. (2000): Evolving Patterns of International Trade. Review of International Economics, 8/3. sz. 373-396.

Redding, S. (1999): Dynamic Comparative Advantage and the Welfare Effects of Trade. Oxford Economic Papers, 51/1. sz. 15-39.

Richardson, J. D. - Zhang, C. (1999): Revealing Comparative Advantage: Chaotic or Coherent Pattern across Time and Sector and U.S. Trading Partner. NBER Working Paper, 7212. sz. Cambridge.

Shorrocks, A. (1978): The measurement of mobility. Econometrica, 46 évf. 1013-1024.

\section{Abstract}

We describe the evolving pattern of Hungarian agri-food trade using recently developed empirical procedures based around the classic Balassa Index at various aggregation level and different bechmark between 1992 and 2002. Our results shows a significant geographical differences and across sub-sectors of 1,2, and 3 digit SITC classification. The extent of trade specialisation exhibits a declining trend for all benchmarks; Hungary has lost comparative advantage for a number of product groups over time. The indices of specialisation have also tended to converge. For particular product groups, the indices display greater variation. They are stable for product groups with comparative disadvantage, but product groups with weak to strong comparative advantage show significant variation. 